\title{
O PODER DE REGULAMENTAÇÃO DAS AGÊNCIAS REGULADORAS E O PRINCÍPIO DA LEGALIDADE: LIMITES E POSSIBILIDADES
}

\author{
Maxwel Gomes dos Santos* \\ Hugo Oliveira Veloso" \\ Carlos Victor Muzzi Filho***
}

\section{Resumo:}

Este trabalho analisa a Administração Pública e o poder regulamentar das agências reguladoras no Brasil, a partir da Constituição de 1988. Utilizam-se a pesquisa bibliográfica e o método dedutivo. Constata-se que essas agências foram criadas, no Brasil, em um contexto de transformação do Estado, que buscava afastar-se da intervenção direta na ordem econômica e adotar um modelo gerencial, focado mais na fiscalização e regulação dos serviços públicos, do que em sua prestação direta. Os resultados indicam que os limites do poder regulamentar dessas agências, entretanto, é objeto de controvérsia, face aos limites decorrentes do princípio da legalidade.

Palavras-chave: Administração Pública. Agências reguladoras. Poder regulamentar. Princípio da legalidade. Direito Administrativo.

\section{THE REGULATORY POWER OF REGULATORY AGENCIES AND THE PRINCIPLE OF LEGALITY: LIMITS AND POSSIBILITIES}

\begin{abstract}
:
This work analyzes the Public Administration and the regulatory power of regulatory agencies in Brazil, from the 1988 Constitution onwards. It uses bibliographical research and the deductive method. It appears that regulatory agencies were created in Brazil in a context of transformation of the State, which sought to move away from direct intervention in the economic order and adopt a managerial model, focused more on inspection and regulation of public services, than in their direct. The results indicate that the limits of regulatory power exercised by these agencies, however, are controversial, given the limits arising from the principle of legality.
\end{abstract}

Keywords: Public Administration. Regulatory agencies. Regulatory power. Principle of legality. Administrative law.

\footnotetext{
* Mestrando em Direito (FUMEC/MG). Especialista Lato Sensu em Direito Eleitoral e Processual Eleitoral (CEUCLAR/SP). Professor de Ensino Superior na UNIMONTES. Analista Judiciário no TRE/MG. E-mail: maxwel.santos@unimontes.br

** Mestrando em Direito (FUMEC/MG). Especialista Lato Sensu em Direito Público (Centro Universitário Newton Paiva/ANAMAGES/MG), Controle Externo da Gestão Pública Contemporânea (PUC Minas) e Direito Notarial e Registral (Universidade Anhanguera/UNIDERP). Advogado. E-mail: hugoveloso@ gmail.com

${ }^{* * * *}$ Doutor e Mestre em Direito Tributário (UFMG); Especialista em Direito Público (IEC-PUC/MG). Professor no Mestrado e Graduação em Direito da FUMEC/MG. Advogado, Procurador do Estado de Minas Gerais. Email:muzzi@fumec.br
} 


\section{INTRODUÇÃO}

A percepção acerca do papel da Administração Pública vem evoluindo ao longo do tempo e, no Brasil, ganhou especial relevo com o advento da Constituição da República Federativa do Brasil de 1988 - CRFB/1988, sob o paradigma estruturante do Estado Democrático de Direito. Essa mudança trouxe implicações na compreensão do papel do Estado, das pessoas jurídicas estatais, seus órgãos e agentes. Sob essa perspectiva, também a Administração Pública passou a ser reestruturada e ressignificada.

Sob a Constituição de 1988, pela primeira vez, a Administração Pública ganhou um estatuto constitucional. Assim, no capítulo VII do Título III da Constituição, além de normas específicas sobre os servidores públicos (algo que já existia em constituições anteriores), seu regime jurídico, remunerações e previdência, trouxe normas gerais direcionadas à Administração Pública, como é o caso do caput do art. 37, cujos princípios positivados são aplicáveis à Administração Pública direta e indireta de qualquer dos Poderes da União, dos Estados, do Distrito Federal e dos Municípios.

Foi em um ambiente de transformações e de revisão das normas constitucionais que, no final da década de 1990, o Estado brasileiro buscou se afastar da função de produtor e interventor direto na ordem econômica e transferiu à iniciativa privada, por meio do processo de desestatização, não apenas o exercício de atividades econômicas que eram então exercidas por entes paraestatais (a indústria siderúrgica, a indústria de aviação aérea, entre outras atividade tipicamente econômicas), mas a prestação de serviços públicos, especialmente nos setores de telecomunicações e de energia elétrica (REGO; MARQUES, 2018, p. 188-195). Com efeito, o Estado passou a atuar com maior ênfase na fiscalização e regulação e na busca por eficiência na prestação de serviços públicos. É nesse momento histórico que, no Brasil, começaram a ser criadas as agências reguladoras, por meio das quais o Estado passa a intervir de forma indireta na ordem econômica.

Nesse contexto, este estudo busca analisar o papel da Administração Pública no Brasil, a partir da Constituição de 1988, tendo como recorte o poder regulamentar das agências reguladoras. Uma justificativa de ordem teórica para o estudo reside no fato de que a amplitude desse poder regulamentar tem sido objeto de controvérsia doutrinária e jurisprudencial, face aos limites impostos pelo princípio da legalidade. Outra motivação, de ordem prática, reside no fato de que conhecer mais essa faceta das agências reguladoras é importante, tendo em vista que o impacto dos atos normativos por elas editados recaem sobre 
diversos setores que impactam diretamente na vida e atividades das pessoas: saúde, energia, recursos hídricos, dentre outros.

Este estudo utiliza-se da pesquisa bibliográfica, bem como do método dedutivo. A discussão está estruturada a partir da seção que aborda a administração gerencial e a nova distribuição das funções do Estado; em seguida trata-se do poder de regulamentação e o princípio da legalidade e, na sequência, discutem-se os limites e possibilidades poder de regulamentação e, enfim, são tecidas as considerações finais. Mostra-se, assim, adequado ao temário do "Grupo de Estudo sobre Direito Administrativo e Gestão Pública", por ser reflexão sobre tema clássico do Direito Público, mediante abordagem crítica e reconstrutiva, revistando e discutindo as bases teóricas e dogmáticas da teoria dos serviços públicos e a gestão pública.

\section{ADMINISTRAÇÃO GERENCIAL E A NOVA DISTRIBUIÇÃO DAS FUNÇÕES DO ESTADO}

A Administração Pública, conforme Di Pietro (2018), pode ser compreendida em seu aspecto subjetivo e objetivo. Em sentido subjetivo abrange, basicamente, as pessoas jurídicas, órgãos e agentes incumbidos de exercer a função estatal administrativa. Em sentido objetivo, designa a natureza da atividade exercidas por esses entes, incumbindo, preponderantemente ao Poder Executivo. A distinção feita por Di Pietro, permite diferenciar a função administrativa propriamente dita (a qual abarca o serviço público, a intervenção, o fomento e a polícia), da função política ou de governo, que compreende as atividades colegislativas e de direção, dirigidas a determinar os fins da ação do Estado. Admite, porém, a autora, que a separação existente entre esses dois tipos de função não é precisa.

Assim, a Administração Pública, em sentido amplo, está presente nos três Poderes, sendo mais evidente no Poder Executivo, na medida em que este busca, em maior medida, realizar atos concretos, tendentes à materialização dos fins estatais, e da satisfação das necessidades coletivas (DI PIETRO, 2018).

A percepção acerca do papel da Administração Pública vem evoluindo ao longo do tempo e, no Brasil, ganhou especial relevo com o advento da Constituição da República de 1988, a qual rompendo com o regime autocrático vigente sob a Constituição anterior, adotou como paradigma estruturante o Estado Democrático de Direito (artigo $1^{\circ}$ da CRFB/1988). E essa mudança trouxe implicações na compreensão do papel do Estado, das pessoas jurídicas 
estatais, seus órgãos e agentes. Em outras palavras, a Constiuição passou a ser o paradigma conformador de uma Administração Pública sob nova perspectiva.

Não somente isto. Com a Constituição da República de 1988, o Estado brasileiro passou por um redimensionamento na sua estrutura, nos seus valores e no relacionamento com a sociedade. Trata-se de um modelo em que, ensina José Afonso da Silva (2020), a democracia qualifica o Estado e tende a realizar a síntese do processo contraditório do mundo contemporâneo, como Estado promotor de justiça social, fundado na dignidade da pessoa humana. O Estado Democrático de Direito, assim, incorpora e supera os paradigmas do Estado Liberal de Direito e do Estado Social de Direito que o precederam.

Nessa perspectiva, também a Administração Pública passa a ser reestruturada e ressignificada, de modo que a burocracia e as prerrogativas do Estado fazem sentido se, e somente se, forem compreendidos como meio de concretização de uma sociedade livre, justa e solidária em que o poder emana do povo. O Estado, nesse paradigma, não detém o poder, mas o canaliza, para que seja exercido pelos representates do povo (democracia representativa) ou diretamente (democracia participativa) nos termos da Constituição.

Conforme Luiz Carlos Figueira Melo e Marcella Rosiére Oliveira:

Sabe-se que a Administração Pública vem passando por transformações, principalmente com o advento da Constituição de 1988 (CF/88), que através da afirmação e eficácia dos princípios constitucionais, propôs uma redefinição das relações entre Estado e sociedade no contexto do Estado Democrático de Direito. Nesse sentido, há o reconhecimento dos cidadãos como detentores de poder político pela participação e controle dos serviços públicos (MELO; OLIVEIRA, 2018, p.88).

Rafael Carvalho Rezende Oliveira (2021, p. 1.031) entende que o Estado Democrático de Direito também comporta uma faceta de Estado Regulador, decorrente da incapacidade de o Estado Social resguardar tecnicamente as atividades econômicas e a delegação de serviços públicos aos particulares, bem como a prestação imediata de tais serviços, justificando o perfilhamento a um Estado que regule o exercício de tais concessões e operações. Isso se dá, principalmente, com a redução da máquina estatal, retirando a intervenção estatal direta (prestação) e transmudando-a em indireta (regulação), o que o autor chama de "Estado Subsidiário ou Neoliberal".

Sob a Constituição de 1988, pela primeira vez, a Administração Pública ganha no Brasil um estatuto constitucional. Assim, no capítulo VII do Título III da Constituição, além de normas específicas sobre os servidores públicos (algo que já existia nas nossas 
constituições anteriores), seu regime jurídico, remuneraçõe e previdência, trouxe normas gerais direcionadas à Administração Pública como um todo, como é o caso do caput do art. 37, cujos princípios positivados são aplicáveis à Administração Pública direta e indireta de qualquer dos Poderes da União, dos Estados, do Distrito Federal e dos Municípios.

Quanto ao papel dos princípios no paradigma constitucional, Clémerson Merlin Clève explica que:

A Constituição absorve determinados valores, apresentados na forma de princípios, de modo a garantir os direitos fundamentais e a dignidade da pessoa humana. Não é mais um simples corpo orgânico destinado a estruturar o Estado, os seus órgãos e a desenhar os limites do exercício do poder. Mais do que isso, é, na verdade, a mina, a reserva, a fonte da materialidade do direito, dos valores que singularizam esta ou aquela ordem jurídica, dos compromissos intergeracionais condensados normativamente (CLÈVE, 2004, p. 407).

Sem adentrar a maiores discussões acerca da normativide dos princípios e sua distinção em relação às regras, admite-se, assim como Bonavides, que:

Hoje, os princípios governam ou tendem a governar na doutrina e na jurisprudência dos tribunais a hierarquia normativa das constituições e representam, portanto, o que há de mais avançado, mais novo e característico, mais sólido do constitucionalismo de nosso tempo. Os princípios, como se vê, outrora fontes hermenêuticas de pouca valia e escasso significado para a ordem constitucional, de súbito se tornaram a base normativa mais importante das constituições (BONAVIDES, 2018, p. 560).

Ao tratar da Administração Pública de forma inédita, em capítulo próprio, a Constituição de 1988, além de sua institucionalização, buscou no processo de constitucionalização criar um Estado burocrático moderno, capaz de superar os vícios do passado: uma administração cuja burocracia era autoreferente, marcada pelo patrimonialismo introjetado na cultura brasileira e pela ineficiência.

Passados mais de trinta anos de vigência da Constituição da República de 1988, pode-se afirmar que o regramento constitucional da Administração Pública logrou êxitos e fracassos e se foi, num primeiro momento, objeto de euforia, hoje, é objeto de revisão crítica. Ilustram seus êxitos, a implantação de uma administração mais impessoal e, sem dúvida, mais eficiente do que aquela existente antes da Constituição. Por outro lado permaneceram ou se avultaram distorções que comprometem uma Administração Pública mais racional, mais eficiente e menos autoreferente, como ilustra a dificuldade em se avaliar eficazmente o desempenho de servidores, bem como distorções remuneratórias que se acumulam sob os três 
Poderes (BAPTISTA, ACCIOLY, 2018).

As dificuldades encontradas no percurso de constitucionalização da Administração Pública também ficam evidentes no fato de que o capítulo VII do Título III da Constituição foi um dos que mais sofreram alterações. Com efeito, as normas do texto original da Constituição foram alteradas pelas Emendas Constitucionais: 19/1998, 20/1998, 34/2001, 41/2003, 42/2003, 47/2005, 88/2015, 101/2019, 103/2019, 106/2020 e 109/2021. No momento em que se escreve este trabalho, encontra-se em tramitação na Câmara dos Deputados Federais a Proposta de Emenda à Constituição no 32-A, de 2020, do Poder Executivo, que "altera disposições sobre servidores, empregados públicos e organização administrativa" (BRASIL, 2021).

Ao refletirem sobre os trinta anos da Constituição e seu regramento da Administração Pública, Baptista e Accioly argumentam que:

Como o capítulo da administração pública não resultou do consenso dos grupos dominantes, mas de uma aposta dos juristas na atuação catalisadora do texto constitucional, a resistência à efetividade da maioria de suas normas se revelou grande desde o início. Mesmo porque o acatamento dos comandos ali contidos implicaria a mudança de padrões arraigados na sociedade brasileira. Mirando apenas nas disposições do artigo 37 (um grupo variado de norma que inclui a enunciação de princípios e um amplo estatuto constitucional dos servidores públicos), acham-se casos de êxitos batalhados e de fracassos retumbantes na realização do projeto constitucional. Coexistem nesse capítulo, normas que, contrariando toda a euforia retórica dos primeiros anos de vigência da Carta, até aqui não saíram do papel, e outras que, após processos de disputa, alcançaram razoável sucesso em conformar a ordem jurídico-administrativa. Há situações em que a inobservância da norma se dá com o beneplácido dos três poderes e das instâncias de controle, que, não raro, emprestam ao texto sentidos que permitem a manutenção do status quo anterior à Constituição. (BAPTISTA; ACCIOLY, 2018, p. 62-63).

Há, entretanto, desde os anos 1990 do século passado, um esforço visível de se adequar a Administração Pública ao modelo gerencial vinculado à obtenção de resultados. É nesse contexto que a Emenda Constitucional no 19/1998 inseriu dentre os princípios da administração pública positivados no art. 37 da Constituição o da eficiência. Os serviços públicos, assim, prestados diretamente pelo Estado, ou delegados a terceiros para a execução, deverão levar em conta fatores mensuráveis que permitam averiguar sua eficiência.

O novo perfil da Administração Pública, de modelo gerencial e vinculado à obtenção de resultados, tem sua legitimidade firmemente apoiada na 
eficiência da atuação administrativa, o que além de resultados sociais e economicamente mensuráveis, resta associado à processualidade da ação administrativa, a assegurar a crescente participação dos cidadãos nos processos de tomadas de decisão públicos, sob o resguardo inafastável do respeito aos direitos e garantias individuais e sociais (MELO; OLIVEIRA, 2018, p. 116).

Num ambiente de transformações do Estado brasileiro, são, então, criadas no final da década de 1990 as agências reguladoras. Na medida em que o Estado se afasta da função de produtor e interventor direto na ordem econômica, transfere à iniciativa privada (sem perder a titularidade dos serviços, que permanecem públicos), a execução de diversos serviços que antes prestava diretamente (MESQUITA, 2005).

Com o novo modelo gerencial, o Estado, por meio das agências reguladoras (tipos de autarquias especiais) passou a dar ênfase na função de fiscalização e regulação. Adotou-se a partir daí um modelo de intervenção indireta, em que se desestatizou parte significativa da prestação de serviços públicos, especialmente nos setores de telecomunicações e energia elétrica. Além disso, houve também a flexibilização do monopólio do petróleo e o incentivo à parceria público-privadas na realização de obras de infraestrutura. Registra Luís Roberto Barroso, a essse propósito, que, "por mais paradoxal que possa parecer", a privatização, no caso brasileiro, foi “a alternativa possível de publicização de um Estado apropriado privadamente, embora, é verdade, o modelo escolhido não tenha sido o da democratização do capital" (BARROSO, 2006, p. 62).

Rafael Oliveira (2021, p. 199) esclarece que as agências reguladoras são autarquias especiais às quais se atribuem autonomia administrativa e financeira, incumbindo-lhes exercer a atividade regulatória, que envolve tanto as atividades administrativas tradicionais, como o poder de polícia, com poderes normativos ampliados, para a expedição de normas técnicas àquele determinado setor regulado, além de poderes judicantes para a resolução de lides administrativas.

Historicamente, as agências reguladoras ocupam papel de destaque no molde organizacional da administração norte-americana, sobretudo após a Grande Depressão (1929). Naquele período, o modelo econômico de liberdade negocial levou à quebra da Bolsa de Valores de Nova Iorque, e o Estado precisou intervir, já que o Mercado não se mostrou apto a reerguer-se sozinho. As falhas do mercado foram corrigidas por meio de intervenção na ordem social e econômica, o que se deu por meio da criação das agências reguladoras (OLIVEIRA, 2021). 
É de se notar que para os Estados Unidos da América as agências reguladoras foram criadas como forma de aumentar a interferência estatal na eonomia, por meio da regulação econômica e social. No Brasil, tais agências representaram o contrário, uma forma de afastar a interferência estatal, retirando do Estado o que já não era possível a ele prestar diretamente. Veja-se que lá se abraçou o que antes era absolutamante livre, pautado pelo laissez-faire, já aqui entre nós, liberou-se, por meio da descentralização e da desestatização, o que ao Estado já não interessava (ou não conseguia) manter.

Carvalho Filho (2020) assevera que a criação das agências reguladoras no Brasil refletem a iniciativa de regular e intervir em determinados setores das atividades econômicas e da prestação de serviços públicos e decorreram do denominado poder regulatório, conceituado como sendo uma função estatal de cunho administrativo, orientada ao controle de atividades de interesse social, que é exercido sobre dois setores que são habitualmente executados pela iniciativa privada: os serviços públicos e algumas atividades privadas de relevância social, como é o caso da concessão dos serviços de energia elétrica e as atividades farmacêuticas de produção e comercialização de medicamentos.

\section{O PODER DE REGULAMENTAÇÃO E O PRINCÍPIO DA LEGALIDADE}

Para falar do poder regulamentar das agências reguladoras é necessária uma passagem pelo princípio da legalidade, que visa a combater e mitigar o poder arbitrário do Estado e foi positivado na Constituição da República de 1988, notadamente no artigo $5^{\circ}$, inciso II, o qual prescreve que ninguém será obrigado a fazer ou deixar de fazer alguma coisa senão em virtude de lei. Nessa dicção, ainda que perfunctória, é basilar que se considerem as limitações constitucionalmente estatuídas, para, adiante, compreender o realce e alcance de tal preceito.

Assim, decorre do princípio da legalidade que somente por meio das espécies normativas formalmente concebidas, conforme as regras de processo legislativo constitucional, será possível criar obrigações para o indivíduo, pois, em tese, estariam inseridas na expressão da vontade da comunidade nacional, o povo, do qual emana o poder. No dizer de Alexandre de Moraes: "Com o primado soberano da lei, cessa o privilégio da vontade caprichosa do detentor do poder em benefício da lei." (MORAES, 2020, p. 61)

Moraes salienta que o princípio da legalidade pressupõe o monopólio do Parlamento, a fim de garantir a lei como "fonte máxima do direito": 
- $\quad$ trata-se da sede institucional dos debates políticos;

- $\quad$ configura-se em uma caixa de ressonância para efeito de informação e mobilização da opinião pública;

- $\quad$ é o órgão que, em tese, devido a sua composição heterogênea e a seu processo de funcionamento, torna a lei não uma mera expressão dos sentimentos dominantes em determinado setor social, mas a vontade resultante da síntese de posições antagônicas e pluralistas da sociedade. (MORAES, 2020, p. 127)

Moraes (2020) destaca também que vários doutrinadores entendem o princípio da legalidade mais como uma garantia constitucional, do que um direito individual, já que serve ao indivíduo para impor que injunções de caráter geral sejam criadas somente com observância do devido processo legislativo e com o espécime normativo constitucional adequado. Ademais, que se exprimam na consecução dos objetivos e fundamentos constitucionais.

Jungido a princípio constitucional expresso, a legalidade assegura que os indivíduos somente serão compelidos a cumprir determinado comando quando veiculados por meio de lei em sentido formal. Entretanto, existe, aparentemente, uma divergência intrínseca entre o princípio da legalidade e o poder normativo conferido às agências reguladoras.

Por um lado, há um princípio constitucional de envergadura e, por outro, a possibilidade de as agências reguladoras normatizarem as suas áreas de competência, conferidas, justamente, pela lei. Mas não só, pois a principiologia por detrás do poder normativo está ligada ao princípio da eficiência, caracterizado por ser o princípio que implementou o modelo de administração pública gerencial, voltada para o controle de resultados na atuação estatal, o que faz com que os atos da administração devam ser realizados com a maior qualidade, competência e eficácia possível, com vistas à segurança jurídica, estabilidade social e transparência.

Tércio Sampaio Ferraz Júnior, nessa linha, constrói argumento em favor do poder normativo das agências reguladoras assentado na ponderação entre o princípio da legalidade e o princípio da eficiência, cogitando, assim, de mutação constitucional (FERRAZ JÚNIOR, 2006, p. 285-291). Segundo Ferraz Júnior, o princípio da eficiência, também constante do arcabouço constitucional de princípios da Administração Pública (artigo 37, “caput”, da CRFB/1988), "traz para a discussão constitucional da delegação de competências um elemento novo" (FERRAZ JÚNIOR, 2006, p. 286). Neste trabalho, porém, não se adentra nessa linha de argumentação, embora também ela ofereça subsídio doutrinário para justificar 
o poder normativo das agências reguladoras, optando-se por justificar esse poder normativo diretamente a partir da legalidade.

Assim, é possível afirmar que a questão acerca da constitucionalidade do poder regulamentar das agências reguladoras face ao princípio constitucional da legalidade deve ser inserida em um contexto mais amplo. Assiste-se no Brasil, desde os anos 1990, a um processo de desestatização das funções regulatórias que alcança não somente as agências reguladoras, mas, em alguma medida segue também no sentido de uma espécie de regulação privada ou, noutros casos, de uma autorregulação regulada, como aponta Gustavo Binenbojm:

Como já dito, à vista do ideal pragmático de eficiência regulatória, a potestade estatal perde o status de fonte exclusiva do poder de polícia, ao menos em ambientes econômicos mais complexos e dinâmicos. Da experiência e das necessidades práticas da vida econômica surgem razões que impulsionam a participação cooperativa dos agentes regulados e de outras partes interessadas, mediante mecanismos regulatórios mais ágeis, flexíveis e adaptados às necessidades de cada setor.

Em termos mais gerais, essa nova vertente da regulação é resultado de um amplo processo contemporâneo de descentralização institucional de poderes normativos (BINENBOJM, 2020, p. 321).

Esse fenômeno de expansão da função legislativa foi identificado por Cappelletti (1993) como decorrência da expansão do Estado, a partir do paradigma do Estado de BemEstar Social, que resultou numa radical mudança no próprio papel do Direito e do Estado na sociedade moderna. E esse formidável crescimento do papel do Estado em geral e da função legislativa em particular parece um fenômeno longe de estar concluído e com efeitos também na função jurisdicional e na compreensão do papel dos juízes como produtores de normas jurídicas também.

As leis que criam as autarquias especiais conferem a tais entidades poder normativo técnico, o que na concepção de Carvalho Filho (2020, p. 581) seria ius novum, pois tais normas incorporam ao ordenamento jurídico atos administrativos eminentemente técnicos, complementares das normas gerais da lei instituidora, o que reflete um poder regulamentar amplo e suscita questionamentos acerca de sua constitucionalidade.

Como bem observa Rafael Oliveira (2021, p. 211), as agências reguladoras são autarquias com regime jurídico especial, porquanto dotadas de autonomia reforçada em relação ao ente central, o que se apresenta por dois principais fundamentos: o primeiro que ele nomeia como despolitização (ou "desgovernamentalização"), conferindo tratamento técnico 
às espécies reguladas e trazendo maior segurança jurídica àquele setor regulado; e o segundo, a celeridade na regulação de determinadas atividades técnicas.

A legislação de regência, Lei n. 13.848 de 25 de junho de 2019, no seu artigo $3^{\circ}$, confere às agências reguladoras o regime especial, caracterizado pela ausência de tutela ou de subordinação hierárquica, pela autonomia funcional, decisória, administrativa e financeira e pela investidura a termo de seus dirigentes e estabilidade durante os mandatos, além das demais peculiaridades previstas na respectiva lei.

Aqui se encontra a questão principal a ser debatida nestas linhas: o poder regulamentar das agências é a causa da deslegalização das imposições normativas, nos termos da materialidade e formalidade constitucionais? Este estudo defende que, na verdade, trata-se de consequência do processo de desestatização decorrente do agigantamento do Estado, o qual num dado momento resolveu atuar de forma mais gerencial e indireta, num movimento em que transfere para os particulares a execução de diversos serviços públicos e incentiva a exploração de determinadas atividades econômicas de interesse público.

O poder normativo das agências reguladoras, assim, estaria a assentar-se, nos princípios da legalidade e da eficiência. Não seriam propriamente os regulamentos normas autônomas em sentido pleno, posto que somente a lei é geral e abstrata, inova na ordem jurídica e a todos alcança. Contudo, nas matérias técnicas que regula, não há como deixar de reconhecer o caráter complementar e ao mesmo tempo autônomo dos regulamentos produzidos pelas agências reguladoras. Este assunto será desenvolvido na seção que segue.

\section{LIMITES E POSSIBILIDADES DO PODER DE REGULAMENTAÇÃO}

O artigo 174 da Constituição da República de 1988 permitiu, genericamente, a criação de autarquias especiais a fim de regular e fiscalizar determinados setores econômicos de interesse social. Assim, a lei que cria tais entidades concede às agências reguladoras a autonomia para editar atos administrativos normativos de conteúdo técnico, mas respeitando os parâmetros legais, no domínio do setor a ser regulado.

A regulação vem, conforme Moreira Neto (2003), de uma ideia de equilíbrio em que interagem fenômenos complexos. Trata-se de uma atividade dos subsistemas de harmonização, cujo conteúdo se aproxima de regramento, mas abrange atribuições tão variadas quanto o planejamento, a informação, fiscalização e a ordenação. A função regulatória, contemporaneamente, insere-se nesse contexto de colaboração dos particulares 
com o poder público, em que a sociedade se coloca como produtora e destinatária da atividade normativa dos entes estatais. Pondera Moreira Neto:

\begin{abstract}
A crescente importância dos instrumentos consensuais na governança moderna vem alicerçada em sólidas premissas: aprimorar a governabilidade pelo incremento da eficiência; reduzir o abuso de poder pela ampliação do controle de legalidade; facilitar a aceitação da decisão pela participação legitimatória; melhorar o atendimento dos interesses envolvidos, aperfeiçoando a licitude; elevar o senso de responsabilidade dos administrados sobre a res publica, resultando no aperfeiçoamento do civismo, e garantir maior aceitabilidade social, do que resulta incremento na ordem ( MOREIRA NETO, 2003, p. 110).
\end{abstract}

Por meio das agências reguladoras, o legislador intentou despolitizar a ação dessas autarquias especiais, atribuindo ao corpo técnico a capacidade de normatizar a atividade regulada, retirando-a do âmbito político representativo. Dá-se o nome de deslegalização à essa possibilidade jurídica que permite a edição de normas gerais de caráter técnico, formalizadas por atos administrativos regulamentares em virtude de delegação prevista na respectiva lei criadora da agência.

Em que pese inferir que o poder normativo técnico seria similar às normas legais, $o$ que o particulariza a regulação é a especialidade do setor regulado e a necessidade de compartimentar tecnicamente tal regulamentação, o que não seria possível por meio de lei, seja pela generalidade, seja pela dificuldade em acompanhar o mercado e as tendências, seja pela politização de setores estratégicos.

A controvérsia doutrinária no que diz respeito à (in)constitucionalidade da amplitude e do fundamento do poder normativo conferido às agências reguladoras é aguda. De um lado concentram-se os que defendem a inconstitucionalidade do poder normativo amplo das agências reguladoras, com base na violação aos princípios constitucionais da separação de poderes e da legalidade, o que vedaria a criação de direitos e/ou obrigações "por meio de atos regulatórios editados com fundamento em delegação legislativa inominada" (OLIVEIRA 2021, p. 213). A segunda corrente segue pelo caminho da constitucionalidade do poder normativo técnico ampliado reconhecido às agências reguladoras que podem, portanto, editar atos normativos, respeitando os parâmetros legais, em razão do instituto da deslegalização. Tal entendimento é seguido por José dos Santos Carvalho Filho, Alexandre Santos Aragão, Marcos Juruena Villela Souto e Diogo de Figueiredo Moreira Neto (OLIVEIRA, 2021, p. 214). 
Aqueles que defendem a inconstitucionalidade do poder regulamentar das agências reguladoras partem da premissa de que o texto constitucional só estabeleceu a possibilidade de exercício do poder normativo primário ao Executivo por meio de Medidas Provisórias e Leis Delegadas (artigos 62 e 68, da CRFB/1988, respectivamente) e, sendo os atos normativos, possíveis de serem editados pelas agências reguladoras tidos por infralegais restringir-se-iam à organização e funcionamento interno dessas entidades.

A linha de raciocínio que seguem é no sentido de que o Poder Executivo deteria poder indireto sobre as agências, o que permitiria burlar os princípios constitucionais que limitam o poder normativo do Chefe do Executivo na edição de medidas provisórias e leis delegadas. Tal corrente é acompanhada por Celso Antônio Bandeira de Mello e Gustavo Binenbojm.

Também Maria Sylvia Zanella Di Pietro segue essa mesma corrente, ao afirmar da impossibilidade de exercício de poder normativo ampliado por parte das agências reguladoras. Entretanto, excepciona agências que possuem fundamento expresso na CRFB/1988, a ANATEL (artigo 21, XI) e a ANP (artigo 177, § 2.o, III) (OLIVEIRA, 2021, p. 214).

Dentro do espectro das teses acima esposadas existe amplo aparato de possibilidades. Contudo, junto com Rafael Oliveira (2021), defende-se que as agências reguladoras podem exercer tal poder normativo, desde que o façam de forma eminentemente técnica, na esfera de suas atribuições, respeitado o princípio da juridicidade. Assim, haveria compatibilidade tanto com o princípio constitucional da legalidade em sentido amplo, como com o princípio da eficiência.

Em consonância com Rafael Oliveira (2021, p. 214), a releitura do princípio da legalidade é que fundamenta tal lógica. A deslegalização significa que o legislador pretendeu retirar do âmbito de atuação legiferante certas matérias, relegando-as aos regulamentos, operando uma "verdadeira degradação da hierarquia normativa (descongelamento da classe normativa) de determinada matéria que, por opção do próprio legislador, deixa de ser regulada por lei e passa para a seara do ato administrativo normativo.” (OLIVEIRA, 2021, p. 214)

O poder normativo das agências reguladoras sustenta-se, portanto, sobre o fundamento da lei que a institui, à qual seguirá vinculada terminantemente, o que faz com que tais normas não possam ser classificadas como absolutamente autônomas (embora exista certamente alguma autonomia) e fruto de delegação legislativa inominada, pois os parâmetros que deverão ser observados pela agência lá se encontram normatizados. 
Não escapa analisar que na "degradação normativa" preconizada pela lei instituidora do ente regulador não retira do legislador o poder de tratar diretamente da matéria deslegalizada, traçando outros standards além dos já tratados na lei primeva, ou mesmo revogando completamente o que já tenha sido legislado a respeito da matéria.

É de se ressaltar que o Supremo Tribunal Federal, no julgamento da ADI 4874, ajuizada pela Confederação Nacional da Indústria (CNI) contra a Resolução da Diretoria Colegiada 14/2012, da Agência Nacional de Vigilância Sanitária (ANVISA), afirmou a constitucionalidade da função normativa dessa agência, ao entendimento de que a "competência para editar atos normativos visando à organização e à fiscalização das atividades reguladas insere-se no poder geral de polícia da Administração sanitária" (BRASIL, 2018).

Novamente com Rafael Oliveira (2021, p. 215), existem, ainda, limites constitucionais à sobredita deslegalização, o que deixa evidenciada a impossibilidade de que tais matérias sejam tratadas por meio do poder de regulamentação das agências reguladoras. Em primeiro lugar citem-se os casos em que há reserva legislativa específica, o que, portanto, devem ser tratados por lei, em seu sentido formal, por exemplo, os incisos VI, VII, VIII e XII do artigo $5^{\circ}$ da Constituição da República de 1988. Em segundo lugar o autor menciona as matérias que devem ser reguladas por meio de lei complementar, por se tratar de reservas legislativas específicas. Em terceiro o autor alude às matérias que, por conterem comando de abrangência federativa, também não admitem a deslegalização, como, por exemplo, os $\S 2^{\circ} \mathrm{e}$ $\S 3^{\circ}$ do artigo 24 da Constituição da República de 1988.

Na compreensão dos limites ao poder de regulamentação das agências deve-se ter em conta que o que a doutrina chama de "revogação diferida", que seria a emissão de ato regulatório posteriormente a determinada lei, o que poderia constituir-se em conflito normativo e qual prevaleceria, neste caso.

A doutrina que advoga contrariamente ao poder normativo das agências afirma que a lei prevalecerá, em qualquer hipótese aventada, fincando sua sustentação na carência da possibilidade de que as agências possam emitir atos normativos com caráter geral e abstrato.

De outro bordo, os que defendem a existência do poder normativo ampliado das agências e, portanto, aceitam que haveria a revogabilidade da lei preexistente, se baseiam na especialidade ínsita à própria deslegalização, sugerida pelo novo aspecto administrativo da governança gerencial. A segunda hipótese doutrinária parece mais fundamentada, porquanto a opção legislativa de criação de uma agência, configurada na descentralização especializada da 
máquina pública, é quem vai ditar a revogação, e não o ato administrativo posteriormente emitido pela agência.

Se a normativa proferida pela agência, que se fundamenta em lei criadora, submetese aos parâmetros desta, deve preponderar em detrimento da lei anterior e que com ela, em tese, conflita. É que não haveria a primazia do ato administrativo sobre a lei anterior, mas quando a lei, dita deslegalizadora, permite o tratamento daquela determinada matéria por meio da agência, o legislador confere, de forma diferida, que, por meio de atos administrativos normativos regulatórios, sejam escanteadas as leis anteriores que com eles conflitem. (OLIVEIRA, 2021, p. 215)

Ainda neste pormenor, é de se lembrar que a lei deslegalizadora fixa apenas as bases sobre as quais as agências firmarão sua influência, ou seja, não minudencia os parâmetros técnicos a serem atendidos pelo setor regulado, do contrário atentaria contra o próprio preceito da criação das agências, que é subverter a lógica de influência política em setores eminentemente técnicos.

Também não escapa aos olhos da doutrina o conflito normativo entre os regulamentos presidenciais (na forma do artigo 84, II, da CRFB) e os atos normativos emitidos pelas agências reguladoras. E, mais uma vez, existem dois entendimentos: há os que entendem pela prevalência do regulamento presidencial, com espeque na superioridade hierárquica do chefe do poder Executivo sobre toda a Administração Pública, tese defendida por Maria Sylvia Zanella Di Pietro (DI PIETRO, 2005, p. 212). Por outro lado, em razão do princípio da especialidade, para a outra corrente capitaneada por Gustavo Binenbojm, haveria a primazia do ato setorial sobre o regulamento do chefe do Executivo (BINENBOJM, 2020, p. 158).

Este estudo alinha-se à segunda corrente exposta acima, porquanto os atos normativos emanados pela agência reguladora possuem caráter técnico e setorial e se fundamentam no artigo 174 da Constituição, enquanto o regulamento presidencial detém conteúdo político e genérico, devendo prevalecer o ato normativo da agência, por sua especialidade. Além disso, no que diz respeito à preconizada hierarquia, as agências reguladoras não são órgãos públicos, mas sim, pessoas jurídicas criadas por lei de iniciativa do próprio chefe do Poder Executivo que, ao iniciar o processo legislativo referenda a necessidade de descentralização das atividades e reconhece a autonomia que será conferida àquela autarquia especial dada à complexidade inerente aos setores regulados. 
Gustavo Binenbojm (2014, p. 35) pontua que houve na segunda metade do século XX um movimento de desconfiança generalizada no legislador, consequentemente de degradação e de desprestígio da lei formal. Fato caracterizado pela descrença de que a lei refletia a vontade do povo. Segundo o autor, o enfraquecimento da lei formal, base da criação de deveres no âmbito jurídico-formal, só pode ser substituído pela constitucionalização do direito administrativo, por meio do qual a setorização excessiva, dada à multiplicação de agências reguladoras (ordenamentos administrativos setoriais) só seria possível dentro dos parâmetros principiológicos constitucionais:

A tais riscos, criados pelo enfraquecimento da lei formal e pela multiplicação dos ordenamentos administrativos setoriais, propõe-se como resposta a constitucionalização do direito administrativo. Deve ser a Constituição, seus princípios e especialmente seu sistema de direitos fundamentais, o elo de unidade a costurar todo o arcabouço normativo que compõe o regime jurídico administrativo. A superação do paradigma da legalidade administrativa só pode dar-se com a substituição da lei pela Constituição como cerne da vinculação administrativa à juridicidade.

Verifica-se, assim, o surgimento de uma verdadeira Constituição administrativa, que, por um processo de autodeterminação constitucional, se emancipou da lei na sua relação com a Administração Pública, passando a consagrar princípios e regras que, sem dependência da interpositio legislatoris, vinculam direta e imediatamente as autoridades administrativas. A Constituição, assim, deixa de ser mero programa político genérico à espera de concretização pelo legislador e passa a ser vista como norma diretamente habilitadora da competência administrativa e como critério imediato de fundamentação e legitimação da decisão administrativa. (BINENBOJM, 2014, p. 36-37)

Retoma-se, aqui, aquela perspectiva exposta ao início deste trabalho, no sentido de que sob o paradigma do Estado Democrático de Direito, a Administração Pública passa a ser reestruturada e ressignificada. Daí, o Direito Administrativo moderno não é mais aquele que se firmou e prevaleceu durante a maior parte do século XX, caracterizado por uma Administração Pública verticalizada em relação ao cidadão, ciosa de suas prerrogativas e exorbitâncias. Com efeito, o Direito Administrativo legal cede lugar ao Direito Administrativo Constitucional, em que a atividade normativa também é compartilhada com a sociedade, produtora e destinatária da atividade legislativa e colegislativa estatal, de modo que é legítimo falar em função reguladora de outros agentes produtores, em decorrência da complexidade da vida moderna, sem que isso represente qualquer diminuição ao Poder Legislativo e suas competências. 


\section{CONSIDERAÇÕES FINAIS}

Sem qualquer pretensão de esgotar a matéria trabalhada no presente estudo, mas no intuito de se propiciar reflexão acerca da legitimidade do poder normativo das agências reguladoras como fator de deslegalização, pode-se concluir que existem ao menos duas correntes que se digladiam entre a possibilidade ou não da delegação indireta do poder normativo conferido às agências reguladoras, tendo como referência o princípio da legalidade.

O presente estudo defende que a tese da deslegalização não é somente sedutora, mas factível. Não se pode legislar sobre todos os fenômenos sociais e econômicos, sobretudo em tempos de disrupção intelectiva. O legislador brasileiro é a síntese da pluralidade da sociedade nacional, cabendo-lhe traçar os parâmetros legais para que o poder regulamentar seja exercido pelas agências reguladoras, em vista do tecnicismo impregnado nos vários âmbitos de atuação, bem como da peculiaridade de mercados e players.

Cabe, na perspectiva aqui adotada, às agências reguladoras tão somente o poder de instituir a regulamentação acerca de matérias de ordem técnica, que, por ser extremamente especializada, não poderia mesmo estar disciplinada na lei.

Concebe-se, assim, uma forma legítima de atuação do Poder Executivo, a quem cabe atuar mais diretamente na administração pública objetiva, evitando-se, por meio das agências reguladoras, que haja a cooptação política de setores regulados.

As autarquias especiais devem ser suficientemente fortes para suportar as várias frentes de interesses antagônicos ao interesse público. Apesar de a deslegalização, causada pelo poder normativo legado às agências, suscitar questionamentos quanto à sua constitucionalidade, não parece haver motivos suficientes para a proibição de sua instituição. A análise deve ser casuística sobre se foi, ou não, regular o exercício do poder por parte da entidade.

\section{REFERÊNCIAS BIBLIOGRÁFICAS:}

BARROSO, Luís Roberto. Agências reguladoras - Constituição - Transformações do Estado e legitimidade democrática. In: Agências reguladoras e democracia. BINENBOJM, Gustavo (coordenador). Rio de Janeiro: Lumen Juris, 2006, p. 59-87.

BATISTA, Patrícia; ACCIOLY, João Pedro. A administração pública na Constituição de 1988. Trinta anos depois: disputas, derrotas e conquistas. Revista de Direito Administrativo, Rio de Janeiro, v. 277, n. 2, p. 45-74, maio/ago. 2018. Disponível em: 
https://bibliotecadigital.fgv.br/ojs/index.php/rda/article/view/76704. Acesso em: 01 ago. 2021.

BINENBOJM, Gustavo. Poder de polícia, ordenação, regulação: transformações políticojurídicas, econômicas e institucionais do direito administrativo ordenador. 3 ed. Belo Horizonte: Forum, 2020.

BINENBOJM, Gustavo. Uma teoria do direito administrativo: direitos fundamentais, democracia e constitucionalização. 3 ed. rev. e atual., Rio de Janeiro: Renovar, 2014.

BONAVIDES, Paulo. Teoria Geral do Estado. 11. ed., rev. e atual, São Paulo: Malheiros, 2018.

BRASIL. [Constituição (1988)]. Constituição da República do Brasil de 1988. Brasília, DF: Presidência da República, [2020]. Disponível em:

http://www.planalto.gov.br/ccivil_03/constituicao/constituicao.htm. Acesso em: 05 set. 2021.

BRASIL. Supremo Tribunal Federal. ADI 4.874/DF. Rel. Min. Rosa Weber. Julgado $1^{\circ}$ fev. 2018. Disponível em:

https://redir.stf.jus.br/paginadorpub/paginador.jsp?docTP=TP\&docID=749049101. Acesso em: 14. set. 2021.

BRASIL. Lei 13.848 de 25 de junho de 2019. Dispõe sobre a gestão, a organização, o processo decisório e o controle social das agências reguladoras. Brasília, DF: Presidência da República, 2020. Disponível em: http://www.planalto.gov.br/ccivil_03/_ato20192022/2019/lei/113848.htm. Acesso em: 06 de set. 2021.

BRASIL. Câmara dos Deputados. Proposta de Emenda à Constituição no 32-A, de 2020, do Poder Executivo, que "altera disposições sobre servidores, empregados públicos e organização administrativa" . Brasília, DF: Câmara dos Deputados, [2020]. Disponível em https://www.camara.leg.br/proposicoesWeb/prop_imp;jsessionid=node01 pazglcmyfvqy1 vrjyy 6km4dj69758996.node0?idProposicao=2262083\&ord=1\&tp=completa. Acesso em: 01 ago. 2020.

CAPPELLETTI, Mauro. Juízes legisladores? OLIVEIRA, Carlos Alberto Alvaro de (Trad.). Porto Alegre: Sérgio Antônio Fabris Editor, 1999 [1993].

CARVALHO FILHO, José dos Santos. Manual de direito administrativo. 34. ed. São Paulo: Atlas, 2020.

CLÈVE, Clèmerson Merlin. Direito constitucional, novos paradigmas, constituição global e processos de integração. In: 15 anos de Constituição. SAMPAIO, José Adércio Leite (Org.). Belo Horizonte: Del Rey, 2004.

DI PIETRO, Maria Sylvia Zanella. Parcerias na Administração Pública: concessão, permissão, franquia, terceirização, parceria público-privada e outras formas. 5. ed. São Paulo: Atlas, 2005.

DI PIETRO, Maria Sylvia Zanella. Direito administrativo. 31. ed. rev. atual. e ampl., Rio de Janeiro: Forense. 2018. 
FERRAZ JÚNIOR, Tércio Sampaio. O poder normativo as agências reguladoras à luz do princípio da eficiência. In: O poder normativo das agência reguladoras. ARAGÃO, Alexandre (coordenador). Rio de Janeiro: Forense, 2006, p. 271-297

MELO, Luiz Carlos Figueira; OLIVEIRA, Marcella Rosiére de. O perfil da Administração Pública no século XXI: uma releitura à luz dos direitos fundamentais. Revista Digital de Direito Administrativo, vol. 5, n. 2, p. 97-118, 2018. Disponível em: https://www.revistas.usp.br/rdda/issue/view/10758. Acesso em: 31 jul. 2021.

MESQUITA, Alvaro Augusto Pereira. O papel e o funcionamento das Agências Reguladoras no contexto do Estado brasileiro: problemas e soluções. In: Revista de Informação Legislativa, Brasília a. 42 n. 166 abr./jun. 2005. Disponível em: http://www2.senado.leg.br/bdsf/handle/id/428. Acesso em: 01 ago. 2021.

MORAES, Alexandre de. Direito constitucional. 36. ed., São Paulo: Atlas, 2020.

MOREIRA NETO, Diogo de Figueiredo. Direito regulatório. Rio de Janeiro: Renovar, 2003.

OLIVEIRA, Rafael Carvalho Rezende. Curso de direito administrativo. 9. ed., Rio de Janeiro: Forense. Método, 2021.

REGO, José Márcio; MARQUES, Rosa Maria (organizadores). Economia brasileira. 6 ed. São Paulo: Saraiva, 2018.

SILVA, José Afonso. Curso de Direito Constitucional Positivo. 43. ed., rev. e atual. São Paulo: Malheiros, 2020. 